\section{FEATURE}

\section{Office for National Statistics}

\section{SUMMARY}

The five previous articles represent a progress report on a project launched in the autumn of 2008 by the Office for National Statistics (ONS) in response to the financial crisis. This concluding article outlines a number of recommendations from this project - aimed at improving the measurement of the UK financial sector activities and the development of sectoral balance sheets for analysis and policy.

\title{
The way forward: conclusions and recommendations
}

\section{The corporate sector}

K National Accounts capture the
majority of financial activity, and
of holdings of financial assets and liabilities across all sectors. However, there are gaps which fall, not surprisingly, in areas where the products and the transactions are complex and in many cases opaque:

- the recording of transactions in structured financial products, such as derivatives and hedge funds, and

- the activity and holdings of securities dealers, venture capital companies, private equity funds and special purpose entities

\section{Recommendation 1}

ONS should publish, after consulting other stakeholders, the analysis it has done on gaps in definition and coverage of reporting on financial services, products and entities as a basis for future joint work.

\section{Recommendation 2}

A forum for active cooperation with the Financial Services Authority (FSA), Bank of England and HM Treasury and other stakeholders should be developed, with a view to filling the gaps, and improving existing data. This forum should also consider proposals from the Office for National Statistics (ONS) to update the presentation of UK Financial Statistics.

Some of the gaps, and areas where existing National Accounts estimates need improvement, have already been prioritised.
However, since resources are limited, it will be necessary to keep progress and finances under review and to recruit support from others.

\section{Recommendation 3}

Data on derivatives are available and should be incorporated into the National Accounts at the earliest opportunity, which is likely to be Blue Book 2010.

\section{Recommendation 4}

A review of bonds transactions and holdings should be carried out, focusing on the reconciliation of data between the income and capital account and measures in the financial account.

\section{Recommendation 5}

Estimates of the gross trading profits of fund managers should be improved, given that they are thought to have been underestimated since the cessation of the fund management inquiry in 2000. This will require creation of new data sources, perhaps in collaboration with other stakeholders.

\section{Recommendation 6}

Estimates of the gross trading profits from asset finance activity should be broken down by asset type, which in turn will improve the validation of finance leasing data. This may be achievable for Blue Book 2010.

\section{Recommendation 7}

A top-to-bottom account for banks should be developed to improve quality assurance 
and sectoral balancing. Work has started on this in ONS, but it requires further input, and data, from the Bank of England.

Gaps and issues relevant to the shortterm (quarterly) measurement of the output of the financial services sector have also been identified.

\section{Recommendation 8}

A volume measure of the output of hedge fund managers is needed, given that they are estimated to make up around 6 per cent of fund management activity, and that there is a wider push for more transparency. ONS should work closely with the FSA in this area to secure the source data and resources required.

\section{Recommendation 9}

The quarterly output of financial advisors and mortgage brokers is not currently measured, and potential data sources should be investigated.

\section{Recommendation 10}

ONS' work on improving its price indices for deflating banking sector output should be revisited, and use of the current deflator (average earnings index (AEI) for financial intermediation, excluding bonuses) reviewed.

ONS recognises that there are issues with its surveys of financial corporations (other than banks and building societies):

- the quarterly surveys of financial flows (transactions) suffer from incomplete coverage, inconsistency of data requested across survey forms, small sample sizes

- the annual surveys of balance sheet data do not cover securities dealers, or the managers of hedge funds and private equity funds, and

- the financial balance sheets of private non-financial corporations (PNFCs) are covered by a quarterly survey, but collect much more data on assets than liabilities

These issues should be addressed as part of a more wide-ranging strategy to improve the coverage and data quality of ONS surveys. With particular reference to the financial sector, the strategy includes:

- investigation of new registers to improve coverage of the financial sector

- improvement of the reconciliation between quarterly and annual data

- assessment of the potential use of administrative data especially regulatory data from the FSA, and

- review of the financial surveys carried out in other countries where balance sheet, flows and revaluation data are collected on a single quarterly survey form

\section{Recommendation 11}

Development of the Securities Dealers' Inquiry should be treated as a priority, including finding solutions to existing data discontinuities and conceptual difficulties with deflation. Some progress will be made over the next year, but full implementation in National Accounts may take until 2012.

\section{The household sector}

ONS is currently reviewing data sources for the household sector balance sheets in the National Accounts. Work is being concentrated on improving the estimates for unquoted shares, the first conclusions for which are likely to emerge in 2010.

ONS recognises the user demand for more detailed data on household assets and liabilities, in particular debt. The first results of the new survey, the Household Assets Survey (HAS), covering the period July 2006 to June 2008 (Wave I) will be available towards the end of 2009 and will include analysis of the assets, liabilities and net wealth of households. One chapter will be dedicated to household debt, and will focus on non-mortgage borrowing and arrears. There will also be a chapter on people's attitudes to saving, borrowing and retirement. A follow-up survey looking at indebted households in more detail, started in October 2007, and looks at households at risk of financial exclusion.

\section{The public sector}

The ONS, Bank of England and HM

Treasury are working closely with the Royal Bank of Scotland and the Lloyds Banking Group to:
- correctly classify all subsidiaries of the two groups

- incorporate the relevant data into the public sector finances, and

- resolve disclosure issues so that more asset and liability detail can be published, in the interests of transparency

\section{Recommendation 12}

ONS should pursue the objective of publishing data separately for the public financial corporations sub-sector, both in the public sector finances, and in the National Accounts. This recommendation covers current work to include public sector banks as part of public sector finances; ONS plans to report further on this by end 2009.

ONS does not systematically publish data on government, or public sector, liabilities which are outside the boundary of public sector net-debt (PSND).

\section{Recommendation 13}

ONS should move progressively towards comprehensive coverage of public sector assets and liabilities, as is the practice of national statistics institutes in some countries. This should start with a feasibility study to show what data can be assembled to improve the overall picture of financial risk. The work on Whole of Government Accounts by HM Treasury should contribute to the solution.

\section{Recommendation 14}

ONS should work actively with Eurostat to develop tables of total pension liabilities in line with the 2008 System of National Accounts (SNA 2008). The first step should be a plan for preparing estimates of funded and unfunded pension liabilities calculated on an actuarial basis, following a workshop in July 2009. This will require liaison with Eurostat and other Member States, working towards production of the supplementary table required, under the European System of Accounts (ESA) Transmission Programme, from 2014.

\section{CONTACT}

elmr@ons.gsi.gov.uk 